\title{
AUSTRIAN NEUTRALITY OF 1955: A MODEL FOR GERMANY OR THE PHENOMENON OF THE COLD WAR?
}

\author{
Aleksei N. Sorokin \\ Dostoevsky Omsk State University, Omsk, Russian Federation
}

\begin{abstract}
Introduction. The article considers the problem of solving the Austrian issue by consolidating the country's neutrality in 1955 in the context of a possible modeling of the situation on the German issue. The consolidation of a neutral non-aligned status with Austria was the result of a broad domestic and foreign policy compromise. At the same time, the main features of the Austrian path to the neutrality of 1945-1955 are highlighted, making this one of the most well-known compromise precedents of the Cold War possible. Methods and materials. The research of the model character of the "Austrian solution" of 1955 is possible only with regard to the intertwining historical contexts in which the development of the German and Austrian issues took place from 1945 to 1949 . The author uses the comparative historical method in the article while comparing historical features of the development of the German and Austrian issues between 1945 and 1955 and comparing different views and concepts of historians. The information base of the article consists of narrative and documentary sources, as well as a wide range of scientific research works of Austrian, German and Russian researchers. Analysis. The main internal reasons for the successful resolution of the Austrian issue are the existence of the pro-Western government elected in 1945, the unity of the main political forces of Austria in the matter of restoring sovereignty, and the personal role of Chancellor Julius Raab. The main international reasons are the change in the course of the USSR within the framework of the peaceful coexistence policy, as well as the reciprocal cooperation policy of the Western Allies. The author considers the problem both in historical and in historiographical perspectives. Results. The possibility of applying the "Austrian solution" to the situation with the divided Germany became the subject of a sharp historiographical dispute, which was called "Model Debate" in Austria. Two famous historians, Rolf Steininger and Michael Gehler, developed a concept confirming the model character of the Austrian solution to the situation with Germany. Most of Austrian historians tend to view the successful resolution of the Austrian issue as a single precedent, or phenomenon, of the Cold War. When comparing the situation with Germany and the attempts to model the Austrian version of it, they point to the different potential and significance of the countries for the Western Allies and the USSR, different goals of foreign policy of victorious powers in the German and Austrian issues.
\end{abstract}

Key words: Austrian history, Austrian historiography, Austrian issue, German issue, Cold War, detente.

Citation. Sorokin A.N. Austrian Neutrality of 1955: A Model for Germany or the Phenomenon of the Cold War? Vestnik Volgogradskogo gosudarstvennogo universiteta. Seriya 4. Istoriya. Regionovedenie. Mezhdunarodnye otnosheniya [Science Journal of Volgograd State University. History. Area Studies. International Relations], 2019, vol. 24, no. 5, pp. 222-235. (in Russian). DOI: https://doi.org/10.15688/jvolsu4.2019.5.16 
ние за Австрией нейтрального внеблокового статуса стало результатом широкого внутри- и внешнеполитического компромисса. При этом выделяются основные особенности австрийского пути к нейтралитету $1945-$ 1955 гг., сделавшие возможным этот один из самых известных компромиссных прецедентов холодной войны. В качестве основных внутренних причин успешного решения австрийского вопроса рассматриваются наличие избранного уже в 1945 г. прозападного правительства, единство главных политических сил Австрии в вопросе восстановления суверенитета, личная роль канцлера Юлиуса Рааба. В качестве главных международных причин выделяются изменение курса СССР в рамках политики мирного сосуществования, а также встречная кооперационная политика западных союзников. Проблема рассматривается как в историческом, так и в историографическом ракурсе. Возможность применения «австрийского решения» к ситуации с разделенной Германией стала предметом острого историографического спора, получившего в Австрии название «дебаты о модели». Два крупных историка, Рольф Штайнингер и Михаэль Гелер, разработали концепцию, подтверждающую модельный характер австрийского решения для ситуации с Германией. Основная часть австрийских историков склонна рассматривать успешное решение австрийского вопроса как единичный прецедент, или феномен, холодной войны. При сравнении ситуации с Германией и попытками моделирования на нее австрийского варианта они указывают на разный потенциал и значение стран для западных союзников и СССР, на различные цели внешней политики держав-победительниц в германском и австрийском вопросах.

Ключевые слова: история Австрии, историография Австрии, австрийский вопрос, германский вопрос, холодная война, разрядка.

Цитирование. Сорокин А. Н. Австрийский нейтралитет 1955 г.: модель для Германии или феномен холодной войны? // Вестник Волгоградского государственного университета. Серия 4, История. Регионоведение. Международные отношения. - 2019. - Т. 24, № 5. - C. 222-235. - DOI: https://doi.org/10.15688/ jvolsu4.2019.5.16

Введение. Вторая мировая война закончилась для Австрии, входившей в состав Третьего рейха, поражением. В апреле 1945 г. союзники заняли ее территорию, страна по аналогии с Германией была разделена на 4 оккупационных зоны, находившихся под управлением СССР, США, Великобритании и Франции. Целое десятилетие австрийский вопрос (проблема государственного суверенитета Австрии после Второй мировой войны и его признания на международной арене) наряду с германским вопросом являлся предметом спора между Советским Союзом, с одной стороны, западными союзниками и сформированным австрийским правительством - с другой. Казалось бы, типичные и практически неразрешимые в разгар холодной войны противоречия. Тем неожиданней было найденное сторонами решение. 15 мая 1955 г. министры иностранных дел Франции, Великобритании, США, Советского Союза и Австрии - Антуан Пине, Гарольд Макмиллан, Джон Фостер Даллес, Вячеслав Молотов и Леопольд Фигль подписали в венском дворце Бельведер «Государственный договор о восстановлении независимой и демократической Австрии». Страна восстанавливала суверенитет в обмен на обязательство принять нейтральный ста- тус, до конца того же года оккупационные войска покинули ее территорию. Вывод советских войск и последующее успешное развитие независимой Австрии породили вопрос о модельном характере «австрийского решения»: насколько оно было применимо для Германии. Как известно, попытки решить подобным образом германский вопрос закончились неудачей. С 1955 г. вопрос, был ли австрийский опыт распространим на Германию, является предметом острой политической, а затем историографической дискуссии. По этой причине исследование возможности решения германского вопроса по примеру австрийского, безусловно, вызывает большой научный интерес.

Дискуссия. Новейшая история Австрии в целом относительно неплохо изучена современной отечественной историографией, публикации по данной тематике представлены как отдельными монографическими исследованиями, так и статьями в журналах, в составе коллективных трудов. Из общих исследований, безусловно, следует выделить учебное пособие Ватлина «Австрия в XX веке» [1], которое является успешной масштабной попыткой изложить новейшую историю Австрии, в том числе проблему нейтралитета 1955 года. Большой исследовательский интерес у отече- 
ственных авторов вызывает и непосредственно проблема возникновения и решения австрийского вопроса. Кроме многочисленных статей отечественных исследователей [2; 5; и др.] были написаны и диссертационные исследования, прямо или косвенно затрагивающие данную тему $[4 ; 10 ; 3$; и др.], и изданы сборники документов со вступительными статьями историков-специалистов по этому вопросу (одни из последних - «Советская политика в Австрии. 1945-1955 гг.» [8] и «СССР и Австрия на пути к Государственному договору» [9]). В качестве одной из известных предметных работ по истории возникновения, эволюции и решения австрийского вопроса можно отметить статью О.В. Павленко «Австрийский вопрос в холодной войне (1945-1955 гг.)» [6]. Вопрос о возможности применения австрийского варианта к решению германского вопроса поднимался отечественными историками, однако развернувшаяся по этому поводу достаточно обширная и интересная полемика в историографии Австрии и Германии фактически остается неизученной отечественными исследователями.

В австрийской и немецкой историографии новейшая история Австрии в целом и австрийский вопрос 1945-1955 гг. в частности проанализированы закономерным образом лучше всего. Проблема австрийского нейтралитета подробно рассмотрена в рамках общих трудов по истории, специализированных монографий и статей. Однако и здесь существует значительный пробел, например в области сопоставления различных точек зрения исследователей на проблему применимости австрийского опыта для Германии, анализа и систематизации развития историографической дискуссии вокруг этой проблемы. Настоящая публикация призвана, прежде всего, заполнить именно этот существующий пробел. При этом впервые в отечественный научный оборот вводится широкий круг научно-исследовательской литературы на немецком языке.

Методы и материалы. Важнейшим методологическим принципом является принцип историзма, в соответствии с которым изучаемые проблемы анализируются в становлении и развитии. Исследование модельного характера «австрийского решения» 1955 г. возможно лишь с учетом переплетающихся ис- торических контекстов, в которых происходило развитие германского и австрийского вопросов с 1945 по 1949 год. Из традиционных методов исследования следует выделить проблемно-хронологический и сравнительно-исторический. Проблемно-хронологический метод позволяет сконцентрировать внимание на рассмотрении того или иного компонента изучаемой проблемы в динамике, расчленить более или менее широкую тему на ряд узких проблем, каждая из которых рассматривается в хронологической последовательности. Огромное значение для исследования играет, конечно, сравнительно-исторический метод. Можно выделить следующие основные уровни его применения: сравнение исторических особенностей развития германского и австрийского вопросов с 1945 по 1955 г., сравнение различных взглядов и концепций историков.

В статье ставится цель - на основе привлечения как исторических, так и историографических источников, реконструировать основные особенности решения австрийского вопроса в 1955 г. в сравнении с нерешенным германским вопросом. Исследование опирается на широкий комплекс документальных и нарративных источников. Использованы как официальные документы международного характера (ноты, заявления, меморандумы, соглашения, договоры), так и источники личного происхождения (мемуары). Большое внимание в статье уделено анализу так называемых историографических «дебатов о модели», где в качестве источников использован широкий комплекс научно-исследовательских работ, прежде всего, австрийских и немецких историков.

Анализ. Следует обратить внимание на некоторые особенности исторического развития оккупированных австрийских территорий в сравнении с Германией. Уже первый документ союзников по антигитлеровской коалиции по австрийскому вопросу - Московская декларация 1943 г. - зафиксировал двойственность подходов: в нем говорилось, что Австрия - одновременно и пострадавшая от агрессии Гитлера страна, суверенитет которой должен быть восстановлен, и соучастница преступлений нацизма. Очевиден более неоднозначный и в то же время более мягкий подход, чем к побежденной Германии [30, S. 607-608]. 
СССР пытался захватить инициативу в области национального государственного строительства в послевоенной Австрии, сделав ставку на известного австрийского социал-демократа Карла Реннера, вокруг которого было сформировано Временное правительство с участием коммунистов [6, с. 264-266]. СССР, безусловно, рассчитывал на укрепление своего влияния в послевоенной Австрии, на возможный переход ее в лагерь «народных демократий» [2, с. 216]. Тем неожиданнее и неприятнее были для советского руководства результаты первых послевоенных австрийских выборов в ноябре 1945 г.: их выиграли Австрийская народная партия (АНП) и Социал-демократическая партия Австрии (СДПА), коммунисты же потерпели поражение, набрав только 5,4 \% [6, с. 267]. Лидеры австрийских коммунистов затем оправдывались перед Сталиным, критикуя поспешность выборов (без проведения «предварительной работы») [8, с. 122-124]. Неудачный австрийский опыт заставил СССР оказывать более решительную поддержку коммунистам при организации выборов в других государствах, оказавшихся в сфере его влияния [1, с. 147-148]. Сформированное же австрийское правительство стало проводить прозападный курс. После выборов конца 1945 г. австрийский вопрос во многом утратил значение для СССР, стал в большей мере средством дипломатической борьбы с Западом. В силу этого, а также скромных размеров и геополитического потенциала Австрия стала скорее второстепенным фронтом холодной войны [30, S. 581].

В последующие годы СССР и западные союзники, на стороне которых выступало и австрийское правительство, не могли решить австрийский вопрос. Советское правительство указывало на недостаточный уровень денацификации и неурегулированности территориальных споров с Югославией [6, с. 276-280]. Также стороны не могли договориться по вопросу репараций: СССР требовал значительных выплат и передачи собственности Третьего рейха, в то время как США распространили на Австрию действие «плана Маршалла», отказавшись от финансовых претензий [30, S. 67-85].

Заслуживает упоминания американская инициатива начала 1950-х гг., получившая название «сокращенный договор». В 1952 г. по- сольство США в Москве направило в МИД СССР ноту, в которой предлагался проект мирного договора. Предусматривались восстановление суверенитета и границ Австрии до 1 января 1938 г., отказ от репараций и вывод оккупационных войск [6, S. 228-230]. Австрия поддержала инициативу, выступив с критикой австрийской политики СССР [15, S. 277]. Поскольку содержание документа никак не учитывало советские интересы, проект не получил советской поддержки. Примечательно, что этот американский проект увидел свет через 3 дня после резонансной ноты советского правительства от 10 марта 1952 г., предлагавшей объединение Германии на основе нейтрального статуса [7]. Советскую инициативу западные державы и правительство ФРГ не поддержали. Как отмечает австрийский историк Вольфганг Мюллер, австрийский вопрос оказался заложником ситуации вокруг Германии: Сталин ждал реакции на свое предложение по Германии, не имея никакого интереса и стимула обсуждать проект «сокращенного договора», созданный и обнародованный прежде всего с целью оказать на СССР дипломатическое давление, а не реально решить проблему [21, S. 117]. Долгие годы австрийский вопрос «находился в тени» германского вопроса [27, S. 89-112, 151]. По этой причине захождение в тупик и нарастание противоречий относительно судьбы послевоенной Германии объективно не способствовало решению вопроса восстановления австрийской государственности. В итоге, как отмечает австрийский историк Гелер, освобождение союзниками Австрии заняло больше времени, чем ее оккупация Гитлером [15, S. 276].

Предпосылки для коренного перелома в решении австрийского вопроса наметились в 1953 году. После смерти Сталина Советский Союз перешел к более гибкой и компромиссной внешней политике по отношению к странам Запада, направленной на разрядку напряженности и на стабилизацию своей сферы влияния. В том же году в Австрии пришло к власти коалиционное правительство, которое возглавил лидер АНП Юлиус Рааб, в свою очередь сигнализировавший об изменениях официальной политики по отношению Советскому Союзу [5, с. 60-61]. Прежде всего, он предостерег австрийских политиков и прессу от 
широко распространенной в то время критики СССР, большую известность получила его фраза: «Ничего не принесет, если снова и снова дергать русского медведя, который стоит посреди австрийского сада, за хвост громкими воскресными речами» [24, S. 18]. Восстановление страны декларировалась и действительно стало высшей целью правительства Рааба, одно из первых официальных заявлений которого гласило: «Наша высшая цель во внешнеполитической области остается незыблемой: свобода Австрии» [24, S. 19]. В. Мюллер полагает, что дополнительную заинтересованность Рааба в развитии отношений с Восточной Европой могли стимулировать интересы восточной торговли Австрии (Osthandel), поскольку канцлер сам вышел из малого бизнеса, а также возглавлял в собственной партии союз предпринимателей [20, S. 15]. Рааб был полон решимости преодолеть или смягчить ярко выраженные антисоветские позиции своих партнеров по коалиции, социал-демократов, о чем свидетельствует, например, такая запись из его дневников: «Травля социалистов из-за русофильской политики заходит довольно далеко, но я ее преодолею» [32, S. 61].

Прорыв в австрийском вопросе случился в 1954 - начале 1955 года. На Берлинской встрече министров иностранных дел 1954 г. австрийский нейтралитет впервые стал предметом переговоров и получил предварительное одобрение от всех заинтересованных сторон [29, S. 278]. 1955 г., ознаменовавшийся многими советскими инициативами и практическими шагами по разрядке напряженности холодной войны, стал годом решения австрийского вопроса. В феврале Молотов высказался за скорейшее решение австрийского вопроса, условиями чего должны были стать гарантии невозможности нового аншлюса и внеблоковая принадлежность Австрии [18, S. 24-25]. Австрийское правительство чутко восприняло сигнал, и уже в марте в Москву была направлена нота, содержащая готовность признать нейтралитет и отказаться от размещения иностранных войск [13, S. 353-354]. В ответ австрийскую делегацию пригласили в Москву [13, S. 357].

Ключевые советско-австрийские переговоры состоялись с 12 по 15 апреля в Москве. На переговорах австрийская сторона подтвер- дила свое согласие придерживаться нейтралитета по швейцарскому образцу. Предметом острой дискуссии стал репарационный вопрос [14, S. 258-278]. В итоге было решено, что СССР получит компенсации за нефтяные промыслы и нефтеперегонные заводы в размере 1 млн т сырой нефти ежегодно в течение 10 лет. Выплата 150 млн долл. за немецкие активы была заменена на поставку товаров на аналогичную сумму, за активы Дунайского пароходства предполагалась выплата 2 млн долларов. Все договоренности по итогам переговоров были зафиксированы в меморандуме [22, S. 284-288]. 14 апреля Рааб послал знаменитую радиограмму в Вену: «Австрия будет свободна. Мы получим всю нашу родную землю назад полностью... Это выстрадано, выработано и достигнуто правильной позицией австрийского народа» [24, S. 33].

Хрущев с удовлетворением отметил в своих воспоминаниях: «Австрия оказалась для меня и для всех нас пробным шаром, демонстрацией того, что мы можем вести сложные переговоры и провести их хорошо... мы в своей международной политике сменили детские штанишки на брюки взрослых людей... Выезд Дуньки в Европу оказался успешным, с демонстрацией того, что мы ориентируемся в международных делах и без сталинских указаний» [11].

В мае 1955 г. в Вене состоялось совещание послов держав антигитлеровской коалиции и австрийского правительства, на котором были окончательно согласованы все детали Государственного договора. Советская сторона пошла на уступки, отказавшись от ряда неприемлемых для австрийцев положений, вроде одностороннего обязательства СССР защищать территориальную неприкосновенность Австрии, австрийских долгах за оккупационные расходы или указаний на участие Австрии во Второй мировой войне. 15 мая 1955 г., спустя 10 лет после окончания военных действий, «Государственный договор о восстановлении независимой и демократической Австрии» был подписан и наглядно продемонстрирован восторженным зрителям с балкона дворца Бельведер. Договор зафиксировал недопустимость нового аншлюса, вывод оккупационных войск, ограничение по численности и вооружениям австрийской армии, 
запрет нацистской деятельности [13, S. 380-406]. 26 октября, на следующий день после официального завершения вывода оккупационных войск, австрийский парламент принял декларацию о вечном нейтралитете, ставшую федеральным конституционным законом [13, S. 444].

Заключение Государственного договора 1955 г. явилось историческим событием. Впервые противники в холодной войне смогли путем взаимных уступок и компромиссов прийти к решению сложной международной проблемы [9, с. 16]. При этом главными победителями стали австрийское правительство, проявившее большую дипломатическую гибкость, решимость и единство в достижении цели, и весь австрийский народ, получивший подлинную независимость и воплотивший в жизнь свой шанс последующего успешного развития. В 1957-1958 гг. канцлер Рааб выступил с инициативой решения германского вопроса путем созыва комиссии союзников (с участием экспертов ГДР и ФРГ), которая проверит условия для свободных общенемецких выборов и разработает избирательное законодательство [23]. Модельный характер австрийского решения в этой инициативе проявился не в чистом виде, а заключался в стремлении решить проблему путем прямого диалога великих держав, национальным правительствам предлагалось избрать путь балансирования между блоками [17, S. 111-115]. Инициатива Рааба не получила поддержки. Аденауэр «австрийское решение» попытался использовать один раз и при этом весьма своеобразно и избирательно: зондировал в разговоре с советским послом в ФРГ Смирновым возможность предоставления только ГДР статуса Австрии, что, естественно, не могло стать предметом переговоров для СССР. Подобные попытки адаптировать «австрийское решение» Аденауэра и его министра иностранных дел фон Брентано, по мнению М. Гелера, отражают 2 факта: 1) они никогда не понимали сущности австрийской модели; 2) они не видели в ней возможность аналогичным путем преодолеть раскол Германии [17, S. 114].

Широко известно явное недовольство, которое Аденауэр выражал по поводу решения австрийского вопроса: через 10 дней после заключения договора он назвал происходящее в личной беседе «австрийским свин- ством» $[27, \mathrm{~S} .145]$. Явное неудовольствие вызывала передача Австрии немецкой собственности. По поводу исторической ответственности двух стран известны высказывания Аденауэра, согласно которым «значительные части Австрии были более национал-социалистическими, чем какая-либо часть Германии», и «они прислали нам Гитлера» [27, S. 146]. Официально Аденауэр на съезде ХДС заявил, что перенос австрийского варианта на Германию невозможен, к тому же повлечет изменение политического, экономического и военного соотношения сил не в пользу Запада [31, S. 130]. По свидетельству Крайского, Аденауэр боялся, что решение австрийского вопроса станет «фатальным примером для Германии» [19, S. 461]. В своих воспоминаниях Крайский пишет, что после переговоров в Москве в личной беседе спросил Микояна, может ли подобное решение распространиться и на Германию. Микоян указал, что «нейтралитет состоит из клочка бумаги, в котором он закреплен, поскольку маленькое государство в курсе, какие последствия может иметь для него разрыв договора. Для большого государства, такого, например, как объединенная Германия, это было бы просто клочком бумаги, который может устареть - и что тогда делать? Вести войну?» [19, S. 461]. Крайский заключает, что нейтралитет в тот период (1955 г.) для Германии был недостижим, судить о ситуации 1952 г., предложении «ноты Сталина» ему сложно. Слова Молотова при заключении Государственного договора о том, что он мог бы стать примером для других государств, Крайский относит к таким небольшим государствам НАТО, как Норвегия, Бельгия или Голландия [19, S. 461].

Как отмечалось, возможное решение австрийского вопроса долгие годы находилось в зависимости от решения германского вопроса. При этом германская проблема по своей значимости, масштабам и остроте противостояния, безусловно, стояла на первом месте, но, конечно, просматривались и явные аналогии в развитии перспектив решения обеих проблем. Вопрос нейтралитета Германии стоял на повестке дня, был концептуирован, в частности, в виде ряда советских инициатив, самой известной из которых является нота советского правительства от 10 марта 1952 года. 
В связи с этим в общественно-политической, а затем и исторической мысли правомерно возник и получил развитие вопрос, был ли австрийский опыт применим к Германии.

Ожидаемо наибольшее изучение данная проблематика нашла в работах историков из непосредственно задействованных в этом стран - Германии и Австрии. Особый интерес вызывает творчество авторов, которых можно отнести к «австрийской критической школе» - это труды Рольфа Штайнингера и его ученика Михаэля Гелера. Их исследования стали неотъемлемой частью дискуссии в немецкой историографии вопроса. Штайнингеру и Гелеру принадлежат исследования, проводящие параллель между «австрийским решением» 1955 г. (нейтралитет 1955 г., вывод советских войск и последующее успешное развитие нейтральной Австрии) и возможным решением германского вопроса: авторы обосновывают модельный характер «австрийского решения», анализируют источники, обосновывающее заинтересованность советской стороны в распространении австрийского опыта на Германию, показывающие крайнее недовольство и неуверенность Аденауэра перед лицом успешного решения австрийского вопроса. Позиция Штайнингера и Гелера была оспорена другими историками и породила историографические «дебаты о модели» (так называемые "Modelle-Debatte").

Рольф Штайнингер - убежденный социалдемократ, немецкий историк, долгие годы проработавший в австрийском университете Инсбрука, - известен в немецкоязычной историографии прежде всего своими работами по изучению советской ноты от 10 марта 1952 года. Он стал одним из самых первых и последовательных представителей «теории упущенной возможности», согласно которой с отклонением «ноты Сталина» 1952 г. был упущен шанс к воссоединению, главными виновниками чего стали канцлер ФРГ Аденауэр и западные союзники, отклонившие советские предложения. Не обошел стороной Штайнингер и австрийский вопрос, посвятив ему, в частности, отдельное исследование «Государственный договор. Австрия в тени германского вопроса и холодной войны» [27]. «Сокращенный договор» 1952 г. Штайнингер характеризует как инструмент пропаганды Запада $[27$, S. 116], по- скольку никто не рассчитывал, что подобный документ будет одобрен Кремлем. С помощью него западные союзники хотели вернуть инициативу в австрийском вопросе, показать свою добрую волю Австрии и всему миру и одновременно подвергнуть обструкции СССР. Штайнингер отмечает прямую связь германского и австрийского вопросов: Запад использовал австрийскую карту, чтобы в том числе торпедировать советские инициативы по Германии. После публикации Московского меморандума по итогам совместных советско-австрийских переговоров Аденауэр оказался под давлением: Москва показала, что с ней можно договариваться, к чему не стремилось правительство ФРГ [27, S. 142]. 5 мая 1955 г. вступили в силу Парижские соглашения, ФРГ получила независимость, однако это событие не стало для немецкого народа таким национальным праздником, как подписание Государственного договора в Вене 15 мая - для австрийского. Касаясь модельного характера «австрийского решения» 1955 г., Штайнингер заключает, что если открыто на Западе предпочитали не проводить прямых параллелей между советскими инициативами в австрийском вопросе применительно к ситуации в Германии, то в кулуарах распространение австрийской модели на ФРГ считалось возможным. Но «Аденауэр не был Раабом» [27, S. 152]. При этом автор справедливо отмечает, что и советские инициативы относительно Германии или Австрии (та самая австрийская модель 1955 г.), способные изменить политику западных союзников в германском вопросе, были либо недостаточными, либо появлялись слишком поздно [27, S. 152-154]. Так было и в 1952 г. c «нотой Сталина» накануне включения Германии в ЕОС, и в 1955 г. накануне ратификации Парижских договоров и вхождения ФРГ в HATO. Штайнингер проводит сравнение между приглашением в Москву Рааба и Аденауэра весной 1955 года. Последний не хотел сдвинуться ни на миллиметр, как и в 1952 г.: Хрущев и Булганин были для него «необразованными и примитивными», как он доверительно сообщил западным послам в Москве, а исключение из западного блока, «Рапалло», двойная игра, «австрийское решение» для объединения Германии - «невозможными» [28, S. 500-501]. 
Михаэль Гелер - австрийский ученый, студент и ученик Штайнингера, директор Института новой и новейшей истории Австрийской академии наук в 2013-2017 гг., работающий в немецком университете Хильдесхайма, - посвятил отдельную работу «сокращенному договору» 1952 г. [15]. Он считает, что после обнародования «ноты Сталина» от 10 марта 1952 г., предложившей объединить Германию под нейтральным статусом, «сокращенный договор» стал инструментом дипломатической борьбы западных держав против СССР, в частности, против советской инициативы в германском вопросе [15, S. 252]. Эта западная попытка признается бесполезной в решении австрийского вопроса, отмечается также прямая связь с вопросом германским: поддержка австрийским правительством «сокращенного договора» сыграла на руку Аденауэру и союзникам при отклонении советской ноты по Германии от 10 марта 1952 г. [15, S. 277-278].

Особый интерес вызывает последняя фундаментальная, объемная (1382 страницы) работа Гелера «Модель для Германии? Австрийское решение с государственным договором и нейтралитетом 1945-1955 гг.» [16], в которой он достаточно аргументированно, с привлечением большого количества источников доказывает модельный характер «австрийского решения». Гелер призывает не рассматривать вопрос однозначно и односторонне, как возможность прямого переноса на решение германского вопроса. «Австрийское решение» для него стало доказательством многогранности и многомерности дипломатии и внешней политики СССР, его модельный характер выразился в следующем: в примере успешного многостороннего взаимодействия с СССР западных держав и затронутой страны; в примере снижения конфронтации и напряжения в Европе; в примере достижения лозунга «единство и свобода» за счет невхождения в альянсы и нейтралитета с целью прекратить оккупацию разделенной страны и др. [16, S. 1232]. В ходе исследования Геллер приходит к следующим основным выводам: СССР до ратификации Парижских соглашений в начале 1955 г. настаивал на созыве конференции для решения австрийского и германского вопросов; предотвращение ремилитари- зации и вхождения ФРГ в НАТО было первоочередной задачей советской политики, после ее неудачи появился Варшавский пакт; пропаганда в начале 1955 г. играла меньшую роль, чем, например, при подготовке «ноты Сталина» от 10 марта 1952 г.; Рааб очень разумно и искусно использовал позицию Советского Союза в национальных интересах Вены; западная интеграция ФРГ блокировала в 19491954 гг. и решение австрийского вопроса, но, несмотря на переход в своей германской политике к «риторике двух немецких государств», СССР оставался переговороспособным по вопросу нейтральной Германии, чем Запад и Аденауэр не воспользовались; австрийские политики в 1955 г. осознанно не оперировали модельным характером договора относительно Германии (например, Крайский открыто отвергал все аналогии, Гелер называет его «главным свидетелем обвинения»), чем существенно увеличивали шансы на успех в виде непротиводействия Запада и Аденауэра, избегались прямые ссылки в период подготовки и заключения соглашения, при этом инициатива Рааба 1957-1958 гг. показывает, что в целом подобная возможность не исключалась [16, S. 1233-1235]. Геллер перефразирует знаменитую формулировку «Аденауэр не был Раабом» в «Рааб не был Аденауэром», которая, на его взгляд, точнее: австрийский канцлер после февральского заявления Молотова поехал в Москву, а не в Вашингтон, как Аденауэр перед Женевской конференцией и визитом в СCCP [16, S. 1178].

Среди оппонентов Штайнингера и Гелера в рамках «дебатов о модели» можно выделить историков Геральда Штурца и Бруно Тоса. Штурц является автором фундаментальной работы «За единство и свободу. Государственный договор, нейтралитет и конец оккупации Австрии Западом и Востоком 1945-1955» (4-е изд. 1998 г. - 834 с., включая приложение в виде документов) [30]. Штурц подчеркивает, что идея нейтралитета развивалась и была притягательна для австрийцев в послевоенный период в значительно большей степени, чем в Германии [30, S. 282]. Уже первые послевоенные национальные правительства Реннера и Фигля неоднократно артикулировали нежелание присоединяться к каким-либо военным блокам [30, S. 268-280]. 
По оценке Штурца, с формулой нейтралитета швейцарского типа был найден общий знаменатель, который соответствовал интересам и потребностям безопасности Австрии, западных держав и Советского Союза [30, S. 450]. В разделе «Советская политика по отношению к Австрии весной 1955 г. и ее движущие причины: оборона от НАТО, пример для Германии или большее?» [30, S. 450-485] автор значительное внимание уделяет противостоянию Хрущева с Молотовым, победителем из которого вышла Австрия. Согласно Штурцу для Хрущева ретроспективно «австрийское решение» означало эмансипацию от внешнеполитического доминирования Сталина и Молотова, чему свидетельством служат отрывок из его воспоминаний о «вояже Дуньки в Европу» [30, S. 454-462, 484-485]. Штурц приводит содержание бесед Шерфа с Молотовым, Микояна с Крайским, в которых советские функционеры заявили о сложности применения австрийского решения к Германии ввиду подписания ФРГ Парижских договоров и разных размеров стран (уже упомянутая беседа Крайского с Микояном о клочке бумаги). Штурц выводит три уровня советской политики взаимоувязывания австрийского и немецкого вопросов в 1955 году. Первому уровню соответствовал окончательный переход к политике двух немецких государств, о чем свидетельствовали начавшиеся еще в январе и продолженные в апреле неофициальные консультации по приглашению Аденауэра в Москву [30, S. 473-475]. Второй уровень согласно Штурцу составляла политика неопределенности по отношению к западным державам и ФРГ, которая проявлялась в публичных выражениях о готовности уступок в германском вопросе. Насколько действительно СССР было готово на уступки, в частности, пожертвовать ГДР, свидетельствует осуждение Маленкова в конце января 1955 г. за проекты сдачи дружественного восточногерманского режима после смерти Сталина. Штурц вступает в прямую полемику с Гелером: в отличие от него он видит в советской политике мартаиюня 1955 г. (не в советской риторике!) окончательную расстановку приоритетов в пользу политики двух немецких государств [30, S. 477]. Наконец, третий уровень образовало подчеркивание влияния решения австрийско- го вопроса на Германию, направленное на западную, прежде всего западногерманскую, общественность. Сюда относятся высказывания Молотова при подписании Государственного договора 15 мая и высказывания политиков ГДР в попытке разыграть «национальную» карту в пропагандистской войне за настроения западногерманского населения [30, S. 479-480]. Штурц интерпретирует советскую политику по отношению к Австрии не как оборону от НАТО или модель для Германии, а как свидетельство новой гибкой политики разрядки под лозунгом «мирного сосуществования», которая придавала новое, более важное значение некоммунистическим внеблоковым государствам. Свидетельством этому стал вывод советских баз из Порт-Артура и Порккалы (Финляндия) в 1954-1955 гг., «сенсационный» визит Хрущева в Белград в апреле 1955 года. Конец первой волне разрядки в 1956 г. положили венгерские события и Суэцкий кризис. Также Штурц выделяет большую заслугу дипломатии и дипломатов: самое длительное мирное компромиссное решение в истории XX в. было достигнуто благодаря искусству переговоров и мастерам этого искусства, будь то профессиональные дипломаты или государственные деятели [30, S. 605-606].

Бруно Тосс, немецкий военный историк, обращается к теме в статье «Австрийская модель? Австрийский Государственный договор и германский вопрос 1954-1955» [31]. По его мнению, нейтрализация Германии, которая позволяла бы немцам, в то время уже шокирующим мир своим динамичным потенциалом развития, лавировать между Востоком и Западом, была неприемлема для Запада в отличие от австрийского варианта. Ограниченный экономический и оборонный потенциал Австрии можно было объединить с меньшим риском для всех, чем таковой Германии [31, S. 99, 107]. В период решающих переговоров по Австрии немецкий нейтралитет не стоял на повестке дня не только для западных союзников и Аденауэра, но и для СССР, разочаровавшегося после Парижских соглашений в политике воссоединения Германии. Тосс приводит известные свидетельства Крайского о беседе с Микояном относительно нейтралитета для малых и больших стран [31, S. 126]. Определяя международное значение австрий- 
ского решения, Тосс отмечает, что оно вписывалось в новую стратегию разрядки СССР, включавшую глобальное разоружение и контроль над вооружениями. Также «австрийское решение», по его мнению, явилось показателем перехода Москвы к новой политике поддержки зарождавшегося как раз в то время движения неприсоединения (Бандунгская конференция 1955 г.), воплотившегося также в восстановлении отношений с титоизмом и в новой оценке буржуазно-национальных элит стран третьего мира. Адресатом подобной политики в Европе могли быть маленькие государства, не ангажированные в холодной войне настолько сильно, как Германия. Тосс приходит к выводу, что венский успех неправомерно проецировать на германский вопрос, поэтому «австрийское решение» являлось не моделью для Германии, а прецедентом в процессе разрядки напряженности холодной войны [31, S. 136].

Большинство австрийских исследователей подчеркивают в первую очередь отличия немецкой ситуации от австрийской и выступают преимущественно против возможности переноса австрийской модели на Германию. Известный австрийский историк Вольфганг Мюллер считает маловероятным, что Кремль рассчитывал на полное предотвращение ратификации Парижских соглашений, сигнализируя, что нейтралитет также может открыть путь к воссоединению Германии. Советские ссылки на Австрию как модель для урегулирования германского вопроса в начале 1955 г. он объясняет скорее пропагандистским желанием вызвать в Западной Европе сопротивление вхождению ФРГ в НАТО и ремилитаризации страны [20, S. 24]. Австро-американский историк Гюнтер Бишоф подчеркивает, что сам Рааб не считал австрийское решение моделью для Германии. Он был, напротив, заинтересован в ФРГ, включенной в западную систему союзов, поскольку она создавала нужный противовес советскому влиянию в регионе. По мнению Бишофа, австрийский план СССР не мог быть примером для решения германского вопроса, поскольку в Германии предпосылки были совершенно иными (географический размер, стратегический вес, открытый вопрос границ и др.). Отклоняя австрийский вариант, Аденауэр боялся возможно- го распространения влияния СССР на Западную Европу, в чем находил поддержку западных держав и всего НАТО [12, S. 160-162]. Австрийский историк Раухенштайнер отмечает, что Австрия представляла собой чужеродное тело как для западного блокообразования («Рааб не был Аденауэром»), так и для восточного (СССР был в Австрии также чужеродным телом). Для раскола страны по немецкому сценарию, который, возможно, потребовал бы применения насильственных мер, не было ни повода, ни средств, ни намерений. Согласно Раухенштайнеру западное блокообразование с участием ФРГ заставило СССР поспешить с инициативой решения австрийского вопроса [25, S. 253-257]. Известный французский историк Жорж-Анри Суту подчеркивает, что Государтсвенный договор 1955 г. был феноменом: как СССР, так и западные державы, устраивала одна Австрия и две Германии, и это, возможно, позволило сохранить мир [26, S. 31].

Результаты. Все вышеизложенное позволяет выделить ряд специфических характеристик и отличий австрийского вопроса от германского:

1. В отличие от Германии Австрия изначально рассматривалась союзниками скорее как освобожденное, чем побежденное государство. Восстановление свободы и суверенитета послевоенной Австрии было зафиксировано в Московской декларации 1943 г., от которой никто из союзников впоследствии не отказывался.

2. Важнейшую роль в послевоенной истории Австрии сыграли первые выборы 1945 г., победу в которых одержали буржуазные партии, фактически сразу устранив коммунистов с внутриполитической арены. Четыре оккупационные зоны в отличие от Германии практически сразу получили единое правительство, которое, естественно, заняло прозападные позиции во внутренней и внешней политике, практически сразу исключив вариант превращения страны в «народную демократию» социалистического лагеря. Советский Союз учел свои ошибки при организации последующих «свободных выборов» в ГДР и странах Восточной Европы, но австрийскую ситуацию переиграть уже было нельзя. Наряду с внеблоковым статусом одним из глав- 
ных вопросов для СССР после этого становится размер репараций: Советский Союз хотел получить как можно больше с уже зародившегося капиталистического самостоятельного государства, не претендуя включить его в сферу своего влияния.

3. Австрийский вопрос, в отличие от германского, имел второстепенное значение в рамках начавшейся холодной войны. Маленькая горная страна по своему геополитическому, военному, демографическому, экономическому потенциалу не шла ни в какое сравнение с Германией. Отсюда прикладной, непринципиальный характер австрийского вопроса и гораздо большая готовность союзников по антигитлеровской коалиции идти на компромисс, что показывает весь период развития дискуссии по Австрии с 1945 по 1955 год. В итоге Запад получил свободную прозападную Австрию, пойдя на уступки в вопросе невключения ее в военный блок НАТО, СССР довольствовался репарациями и нейтральным статусом, окончательно зафиксировав и консолидировав сферу своего влияния в Восточной Европе (неслучайно практически одновременно с подписанием Государственного договора с Австрией 14 мая 1955 г. была создана Организация Варшавского договора). Следует отметить, что международная ситуация крайне благоприятствовала Австрии: на первую половину 1955 г. пришелся значительный виток политики разрядки. Советская нота от 10 марта 1952 г. с предложением единства Германии была обнародована, например, совсем в других условиях эскалации международной напряженности и взаимного недоверия, и к тому же в момент заключительной фазы переговоров о принятии ФРГ в западную систему военно-политических союзов (Европейское оборонительное сообщество), поэтому шансы на успех этой инициативы были изначально невелики. В 1955 г. ФРГ была уже членом НАТО, а ГДР окончательно оформилась как государство и вступила в ОВД. Раздробленная Германия ко всему прочему в каком-то смысле больше устраивала западных союзников и СССР, пострадавших от нее во Второй мировой войне.

4. Коренным образом отличалась и внутриполитическая ситуация в ФРГ и Австрии. В Западной Германии 1950-х гг. основные партии-оппоненты на выборах придержива- лись разных внешнеполитических приоритетов. Если СДПГ провозгласила первоочередной задачей восстановление единства нации, то правящая ХДС/ХCС по главе с Аденауэром отдавала безусловный приоритет западной интеграции ФРГ. Вопрос воссоединения, при решении которого в тот период нужно было искать компромисс с СССР, не являлся для первого федерального канцлера первостепенным в отличие от его коллег в Австрии. Вопрос серьезности советских инициатив по нейтральной Германии остается открытым. Но очевидно другое: Аденауэр и западные союзники не хотели даже серьезно тестировать, проверять их, так как вопрос привязки ФРГ к западной системе союзов был для них важнее. Австрийская политика отличалась коренным образом: к власти в 1953 г. пришло национальное коалиционное правительство, которое приложило все усилия для восстановления суверенитета и действовало при этом, как отмечают все исследователи, весьма последовательно и искусно.

Эти основные факторы и обусловили уникальность решения австрийского вопроса в сопоставлении с ситуацией вокруг Германии. Можно ли считать «австрийское решение» в широком смысле (объединение и суверенитет в ответ на внеблоковую принадлежность) моделью для Германии? Этот вопрос остается дискуссионным. Представляется, что, опираясь на известные источники, нельзя полностью исключать интерес СССР к решению германского вопроса в соответствии с австрийским прецедентом, то есть путем закрепления нейтрального, внеблокового статуса страны. Этот вариант, выраженный в ряде инициатив, не был серьезно проработан ввиду позиции западных союзников и ФРГ. В связи с этим можно сделать вывод, что в узком смысле «австрийское решение» остается феноменом холодной войны, возникновению которого способствовал ряд уникальных факторов, неприменимых в конкретной исторической ситуации к Германии. Если же понимать австрийскую модель более широко - как готовность СССР вести переговоры и достигать соглашения с западными союзниками о нейтральном статусе оккупированной страны, - то здесь вопрос относительно Германии остается открытым в силу отклонения западными 
союзниками и ФРГ советских инициатив и в силу отсутствия источников, однозначно раскрывающих советское внешнеполитическое планирование в этом вопросе на протяжении всего периода с 1949 по 1955 год.

\section{СПИСОК ЛИТЕРАТУРЫ}

1. Ватлин, А. Ю. Австрия в ХХ веке/ А. Ю. Ватлин. - М. : Дрофа, 2006. - 240 с.

2. Ворошилов, С. И. 1945 год в Австрии: от ашлюса к демократической республике / С. И. Ворошилов // Вестник Санкт- Петербургского университета. Серия 2, История. - 2007. - № 1. - С. 215-217.

3. Игошкин, Г. С. Внешняя политика Второй Австрийской Республики : дис. ... канд. ист. наук / Игошкин Георгий Степанович. - Киев, 1990. - 280 с.

4. Кружков, В. А. Постоянный нейтралитет Австрии: становление, трансформация и перспективы : дис. ... канд. ист. наук / Кружков Владимир Анатольевич. - М., 2009. - 199 с.

5. Максимычев, И. Ф. Австрия: опыт нейтралитета / И. Ф. Максимычев // Современная Европа. - 2006. - № 3. - С. 56-68.

6. Павленко, О. В. Австрийский вопрос в Холодной войне (1945-1955 гг.) / О. В. Павленко // Новый исторический вестник. - 2004. - № 1 (10). С. 247-295.

7. Проект советского правительства о мирном договоре с Германией // Правда. - 1952. - № 71 (12273).-C. 2.

8. Советская политика в Австрии. 19451955 гг. Сборник документов / под ред. Г. Бордюгова [и др.]. - М. : АИРО-ХХ1 ; СПб. : Дмитрий Буланин, 2006. $-656 \mathrm{c}$.

9. СССР и Австрия на пути к Государственному договору. Страницы документальной истории 1945-1955 / под ред. А. Ю. Ватлина [и др.]. - М. : Политическая энциклопедия, 2015. - 455 с.

10. Ульякин, А. А. Политика США в отношении Австрии в период подготовки и принятия государственного договора: 1945-1955 гг. : дис. ... канд. ист. наук / Ульякин Антон Александрович. - М., 2008. -202 c.

11. Хрущев, Н. С. Воспоминания. Время. Люди. Власть. Книга 2. - Электрон. текстовые дан. - Режим доступа: https://profilib.org/chtenie/112740/ nikita-khruschev-vospominaniya-vremya-lyudi-vlastkniga-2-lib-135.php (дата обращения: 05.10.2018).Загл. с экрана.

12. Bischof, G. Österreichische Neutralität, die deutsche Frage und europäische Sicherheit 1953-1955 / G. Bischof// Die doppelte Eindämmung. Europäische Sicherheit und deutsche Frage in den fünfzigern. München : Hase \& Koehler, 1993. - S. 133-176.
13. Der Weg zu Freiheit und Neutralität. Dokumentation zur österreichischen Außenpolitik 1945-1955 / Csaky E.-M. (Hrsg.). - Wien : Gesellschaft der Freunde der Österreichischen Nationalbibliothek, 1980. $-461 \mathrm{~S}$.

14. Einheit und Teilung. Österreich und die Deutschlandfrage 1945-1960 / Gehler M., Agstner R. (Hrsg.). - Innsbruck, Wien : Studienverlag, 2013. $560 \mathrm{~S}$.

15. Gehler, M. Kurzvertrag für Österreich? Die westliche Staatsvertrags-Diplomatie und die StalinNoten von 1952 / M. Gehler // Vierteljahrshefte für Zeitgeschichte. - 1994.-H. 2.-S. 243-278.

16. Gehler, M. Modellfall für Deutschland? Die Österreichlösung mit Staatsvertrag und Neutralität 1945-1955 / M. Gehler. - Innsbruck : Studienverlag, 2015. $-1382 \mathrm{~S}$.

17. Gehler, M. Neutralität und Neutralisierungspläne für Mitteleuropa? Österreich, Ungarn, Tschechoslowakei und Polen / M. Gehler // Neutralität - Chance oder Chimäre. Konzepte des Dritten Weges für Deutschland und die Welt 1945-1990/ D. Geppert, U. Wengst (Hrsg.). München : Oldenbourg, 2005. - S. 105-132.

18. Kreisky, B. Neutralität und Koexistenz. Aufsätze und Reden / B. Kreisky. - München : List, 1975. $-200 \mathrm{~S}$.

19. Kreisky, B. Zwischen den Zeiten. Erinnerungen aus fünf Jahrzehnten / B. Kreisky. Berlin : Siedler, 1986. -494 S.

20. Mueller, W. A Good Example of Peaceful Coexistence? The Soviet Union, Austria, and Neutrality, 1955-1991 / W. Mueller. - Wien : Verlag der österreichischen Akademie der Wissenschaften, 2011. $-381 \mathrm{~S}$.

21. Mueller, W. Gab es eine "verpasste Chance"? Die Sowjetische Haltung Zum Staatsvertrag 1946-1952 / W. Mueller // Der österreichische Staatsvertrag 1955: Internationale Strategie, rechtliche Relevanz, nationale Identität / A. Suppan, G. Stourzh, W. Mueller (Hrsg.). Wien : Verlag der österreichischen Akademie der Wissenschaften, 2005. - S. 89-120.

22. Österreich und die Grossmächte. Dokumente zur österreichischen Außenpolitik 1945-1955 / A. Schilcher (Hrsg). - Wien; Salzburg: Gezer, 1980. - 359 S.

23. Pappe, M. Die Deutschlandinitiative des österreichischen Bundeskanzlers Julius Raab im Frühjahr1958 / M. Pappe // Vierteljahrshefte für Zeitgeschichte. -2000. - H. 2. - S. 281-318.

24. Raab, J. Verantwortung für Österreich/J. Raab. Wien : Österreichisches Wirtschaftsverlag, 1961.-175 S.

25. Rauchensteiner M. Stalinplatz 4. Österreich unter alliierten Besatzung / M. Rauchensteiner. Wien : Edition Steinbauer, 2005. - 336 S.

26. Soutou, G.-H. Der österreichische Staatsvertrag in der internationalen Politik 1955 / G.-H. Soutou // Der österreichische Staatsvertrag 1955: Internationale 
Strategie, rechtliche Relevanz, nationale Identität / A. Suppan, G. Stourzh, W. Mueller (Hrsg.). - Wien : Verlag der österreichischen Akademie der Wissenschaften, 2005. - S. 17-32.

27. Steininger, R. Der Staatsvertrag. Österreich im Schatten von deutscher Frage und Kaltem Krieg / R. Steininger. - Innsbruck : Studienverlag, 2005. $198 \mathrm{~S}$.

28. Steininger, R. Deutschland, Österreich und die Neutralität 1952-1955 / R. Steininger // Der österreichische Staatsvertrag 1955: Internationale Strategie, rechtliche Relevanz, nationale Identität / A. Suppan, G. Stourzh, W. Mueller (Hrsg.). - Wien : Verlag der österreichischen Akademie der Wissenschaften, 2005. - S. 475-501.

29. Steininger, R. Österreichischer Weg zum Staatsvertrag 1945-1955 / R. Steininger // Die Gunst des Augenblickes. Neue Forschungen zu Staatsvertrag und Neutralität / M. Rauchensteiner, R. Kriechbaumer (Hrsg). - Wien ; Köln ; Weimar : Böhlau, 2005. - S. 273-290.

30. Stourzh, G. Um Einheit und Freiheit: Staatsvertrag, Neutralität und das Ende der Ost-WestBesetzung Österreichs 1945-1955 / G. Stourzh. - Wien ; Köln ; Graz : Böhlau, 1998. - 834 S.

31. Thoß, B. Modellfall Österreich? Der österreichische Staatsvertrag und die deutsche Frage 1954-1955 / B. Thoß // Zwischen Kaltem Krieg und Entspannung. Sicherheits- und Deutschlandpolitik der Bundesrepublik im Mächtesystem der Jahre 1953-1956. - Boppard am Rhein : Harald Boldt Verlag, 1988. - S. 93-136.

32. Wohnout, H. Das politische Tagebuch von Julius Raab 1953/1954. Neue Erkenntnisse zu den ersten Jahren seiner Kanzlerschaft / H. Wohnout, J. Schönner // Demokratie und Geschichte. Jahrbuch des Karl von Vogelsang-Instituts zur Erforschung der Geschichte der christlichen Demokratie in Österreich. Jg. 7/8 (2003/2004). - Wien ; Köln ; Weimar : Böhlau, 2005. - S. 13-71.

\section{REFERENCES}

1. Vatlin A.Y. Avstriya $v X X$ veke [Austria in the $20^{\text {th }}$ Century]. Moscow, Drofa, 2006. $240 \mathrm{p}$.

2. Voroshilov S.I. 1945 god v Avstrii: ot anshlyusa k demokraticheskoy respublike [1945 in Austria: From Anschluss to Democratic Republic]. Saint Petersburg's vestnik, Seriya 2, Istoriya, 2007, no. 1, p. 215-217.

3. Igoshkin G.S. Vneshnyaya politika Vtoroy Avstriyskoy Respubliki: dis. ... kand. ist. nauk [Foreign Policy of the Second Austrian Republic. Cand. hist. sci. diss.]. Kiev, 1990. 280 p.

4. Kruzhkov V.A. Postoyannyy neytralitet Avstrii: stanovlenie, transformatsiya i perspektivy: dis. ... kand. ist. nauk [Stable Neutrality of Austria: Establishment, Transformation and Perspectives: Cand. hist. sci. diss.]. Moscow, 2009. 199 p.

5. Maksimychev I.F. Avstriya: opyt neytraliteta [Austria: Experience of Neutrality]. Sovremennaya Evropa, 2006, no. 3, p. 56-68.

6. Pavlenko O.V. Avstriyskiy vopros v Kholodnoy voyne (1945-1955) [The Austrian Question in the Cold War (1945-1955)]. Novyy istoricheskiy vestnik, 2004, no. 2, p. 247-295.

7. Proekt sovetskogo pravitelstva o mirnom dogovore s Germaniey [The Project of the Soviet Government About the Peace Treaty with Germany]. Pravda, 1952, no. 71 (12273), p. 2.

8. Sovetskaya politika v Avstrii. 1945-1955 [Soviet Policy in Austria. 1945-1955]. G. Bordyugov, W. Mueller, N. Naimark, A. Suppan (Hrsg.). Saint Petersburg, Dmitriy Bulanin, 2006. 656 p.

9. SSSR I Avstriya na puti k Gosudarstvennomy dogovoru. Stranitsy dokumentalnoy istorii 19451955 [USSR and Austria on the Way to the State Agreement. Pages of Documental History of 19451955]. A. Vatlin, B. Kotov, A. Sorokin (Hrsg.). Moscow, Politicheskaya entsiklopediya, 2015. 455 p.

10. Ulyakin A.A. Politika SSHA v otnoshenii Avstrii $v$ period podgotovki $i$ prinyatiya gosudarstvennogo dogovora: 1945-1955: dis. ... kand. ist. nauk [USA Policy Towards Austria in the Period of Preparation and Conclusion of the State Agreement: 1945-1955. Cand. hist. sci. diss.]. Moscow, 2008. 202 p.

11. Khrushchev N.S. Vospominaniya. Vremya. Lyudi. Vlast. Kniga 2 [Memories. Time. People. Power. Book 2]. URL: https://profilib.org/chtenie/112740/ nikita-khruschev-vospominaniya-vremya-lyudi-vlastkniga-2-lib-135.php (accessed 5 October 2018).

12. Bischof G. Österreichische Neutralität, die deutsche Frage und europäische Sicherheit 1953-1955. Die doppelte Eindämmung. Europäische Sicherheit und deutsche Frage in den fünfzigern. München, Hase \& Koehler, 1993, pp. 133-176.

13. Der Weg zu Freiheit und Neutralität. Dokumentation zur österreichischen Außenpolitik 1945-1955. Csaky E.-M. (Hrsg.). Wien, Gesellschaft der Freunde der Österreichischen National bibliothek, 1980, 461 p.

14. Einheit und Teilung. Österreich und die Deutschlandfrage 1945-1960. Gehler M., Agstner R. (Hrsg.). Innsbruck, Wien, Studienverlag, 2013, 560 S.

15. Gehler M. Kurzvertrag für Österreich? Die westliche Staatsvertrags-Diplomatie und die StalinNoten von 1952. Vierteljahrshefte für Zeitgeschichte, 1994, H. 2, pp. 243-278.

16. Gehler M. Modellfall für Deutschland? Die Österreichlösung mit Staatsvertrag und Neutralität 1945-1955. Innsbruck, Studienverlag, 2015. 1382 p. 
А.Н. Сорокин. Австрийский нейтралитет 1955 г.: модель для Германии или феномен Холодной войны?

17. Gehler M Neutralität und Neutralisierungspläne für Mitteleuropa? Österreich, Ungarn, Tschechoslowakei und Polen. Neutralität Chance oder Chimäre. Konzepte des Dritten Weges für Deutschland und die Welt 1945-1990. Geppert, U. Wengst (Hrsg.). München, Oldenbourg, 2005, pp. 105-132.

18. Kreisky B. Neutralität und Koexistenz. Aufsätze und Reden. München, List, 1975. 200 p.

19. Kreisky B. Zwischen den Zeiten. Erinnerungen aus fünf Jahrzehnten. Berlin, Siedler, $1986.494 \mathrm{p}$.

20. Mueller W. A Good Example of Peaceful Coexistence? The Soviet Union, Austria, and Neutrality, 1955-1991. Wien, Verlag der österreichischen Akademie der Wissenschaften, 2011. $381 \mathrm{p}$.

21. Mueller W. Gab es eine "verpasste Chance"? Die Sowjetische Haltung Zum Staatsvertrag 19461952. Der österreichische Staatsvertrag 1955: Internationale Strategie, rechtliche Relevanz, nationale Identität. A. Suppan, G. Stourzh, W. Mueller (Hrsg.). Wien, Verlag der österreichischen Akademie der Wissenschaften, 2005, pp. 89-120.

22. Österreich und die Grossmächte. Dokumente zur österreichischen Außenpolitik 1945-1955. A. Schilcher (Hrsg). Wien, Salzburg, Gezer, 1980, 359 S.

23. Pappe M. Die Deutschlandinitiative des österreichischen Bundeskanzlers Julius Raab im Frühjahr1958. Vierteljahrshefte für Zeitgeschichte, 2000, H. 2, pp. 281-318.

24. Raab J. Verantwortung für Österreich. Wien, Österreichisches Wirtschaftsverlag, 1961. 175 S.

25. Rauchensteiner M. Stalinplatz 4. Österreich unter alliierten Besatzung. Wien, Edition Steinbauer, 2005. 336 p.
26. Soutou G.-H. Der österreichische Staatsvertrag in der internationalen Politik 1955. Der österreichische Staatsvertrag 1955: Internationale Strategie, rechtliche Relevanz, nationale Identität. Wien, Verlag der österreichischen Akademie der Wissenschaften, 2005, pp. 17-32.

27. Steininger R. Der Staatsvertrag. Österreich im Schatten von deutscher Frage und Kaltem Krieg. Innsbruck, Studienverlag, 2005. 198 p.

28. Steininger R. Deutschland, Österreich und die Neutralität 1952-1955. Der österreichische Staatsvertrag 1955: Internationale Strategie, rechtliche Relevanz, nationale Identität. Wien, Verlag der österreichischen Akademie der Wissenschaften, 2005, pp. 475-501.

29. Steininger R. Österreichischer Weg zum Staatsvertrag 1945-1955. Die Gunst des Augenblickes. Neue Forschungen zu Staatsvertrag und Neutralität. M. Rauchensteiner, R. Kriechbaumer (Hrsg). Wien, Köln, Weimar, Böhlau, 2005, pp. 273-290.

30. Stourzh G. Um Einheit und Freiheit: Staatsvertrag, Neutralität und das Ende der Ost-WestBesetzung Österreichs 1945-1955. Wien, Köln, Graz, Böhlau, 1998. 834 p.

31. Thoß B. Modellfall Österreich? Der österreichische Staatsvertrag und die deutsche Frage 1954-55. Zwischen Kaltem Krieg und Entspannung. Sicherheits- und Deutschlandpolitik der Bundesrepublik im Mächtesystem der Jahre 1953-1956. Boppard am Rhein, Harald Boldt Verlag, 1988, pp. 93-136.

32. Wohnout H., Schönner J. Das politische Tagebuch von Julius Raab 1953/1954. Neue Erkenntnisse zu den ersten Jahren seiner Kanzlerschaft. Demokratie und Geschichte. Jahrbuch des Karl von VogelsangInstituts zur Erforschung der Geschichte der christlichen Demokratie in Österreich. Jg. 7/8 (2003/2004). Wien-Köln, Weimar, Böhlau, 2005, pp. 13-71.

\section{Information about the Author}

Alexey N. Sorokin, Candidate of Sciences (History), Associate Professor, Department of History and Theory of International Relations, Dostoevsky Omsk State University, Prosp. Mira, 55A, 644077 Omsk, Russian Federation, SorokinAN@omsu.ru, https://orcid.org/0000-0001-7942-7266

\section{Информация об авторе}

Алексей Николаевич Сорокин, кандидат исторических наук, доцент кафедры истории и теории международных отношений, Омский государственный университет им. Ф.М. Достоевского, просп. Мира, 55A, 644077 г. Омск, Российская Федерация, SorokinAN@omsu.ru, https://orcid.org/0000-0001-7942-7266 